\title{
Characterization of some bottled Romanian mineral waters on the basis of the total mineral content
}

\author{
K. Bodor ${ }^{1,2,3}$
}

e-mail: bodorkatalin@uni.sapientia.ro

$$
\text { R. Szép }{ }^{1,2,3}
$$

e-mail: szeprobert@uni.sapientia.ro

\author{
Zs. Bodor ${ }^{1,2}$ \\ e-mail: bodorzsolt@uni.sapientia.ro
}

A. Szép ${ }^{4^{*}}$

e-mail: alszep@uni.sapientia.ro

${ }^{1}$ University of Pécs, Faculty of Natural Sciences, Doctoral School of Chemistry, HU-7624 Pécs, 6 Ifjúság St.

${ }^{2}$ Sapientia Hungarian University of Transylvania (Cluj-Napoca, Romania), Faculty of Economics, Socio-Human Sciences and Engineering, Department of Bioengineering, RO-530104 Miercurea Ciuc, 1 Libertăţii Sq.

${ }^{3}$ Institute for Research and Development of Hunting and Mountain Resources, RO-530240, Miercurea Ciuc, 35B Progresului St.

${ }^{4 *}$ Sapientia Hungarian University of Transylvania (Cluj-Napoca, Romania), Faculty of Economics, Socio-Human Sciences and Engineering, Department of Food Science, RO-530104 Miercurea Ciuc, 1 Libertăţii Sq.

\begin{abstract}
Romania has many mineral water sources due to its geological features. In the present study, bottles of 26 Romanian mineral water brands were purchased from the market to make a characterization based on the $\mathrm{pH}$, conductivity, and fixed residue content. Focusing on the total fixed residue, the distribution of low, medium, and highly mineralized water was $43.9 \%, 41.46 \%$, and $14.63 \%$ respectively. The mean of fixed residue concentration was $763.3 \mathrm{mg} / \mathrm{L}$, ranging from $40.37 \mathrm{mg} / \mathrm{L}$ to 2,603 $\mathrm{mg} / \mathrm{L}$. The $\mathrm{pH}$ values of the still mineral waters varied between 6.86 and
\end{abstract}

Keywords and phrases: mineral water, $\mathrm{pH}$, conductivity, fixed residue, cluster analysis 
7.91, while the $\mathrm{pH}$ values of the sparkling mineral waters were the lowest (4.7). The conductivity was strongly related to the concentration of the ions, so the maximum measured conductivity for the still waters was $573 \mu \mathrm{S} / \mathrm{cm}$, for the partially sparkling waters $2,133 \mu \mathrm{S} / \mathrm{cm}$, and for the sparkling mineral waters $3,079 \mu \mathrm{S} / \mathrm{cm}$. The chemical composition of the mineral waters was highly dependent on the rock types. Using the hierarchical cluster analysis, two different clusters were detected according to the main characteristics of mineral waters.

\section{Introduction}

Romania owns $60 \%$ of the hydro-mine sources in Europe, but only one-fifth of these resources are exploited (FRD Center Market, 2016). According to the EU legislation (80/777/EEC): "mineral water is microbiologically wholesome water from an underground aquifer tapped via one or more natural or drilled wells" (The Council of the European Communities, 1980). According to the definition of the Food and Drug Administration, mineral water contains at least $250 \mathrm{mg} / \mathrm{L}$ of dissolved solids originated from a biologically and physically protected underground water source (Sharma, 2017).

According to the literature, the most significant mineral water source with high $\mathrm{CO}_{2}$ content is found in the Eastern Carpathians due to the Oaş-GutâiCălimani-Harghita volcanic chain (Ionete et al., 2015; Vaselli et al., 2002).

The World Health Organization's (WHO) recommendations for the average daily water requirements for women, men, and children are $2.2 \mathrm{~L}, 2.9 \mathrm{~L}$, and $1.0 \mathrm{~L}$ respectively. In the case of hard physical work at elevated temperature, this requirement may be increased to $4.5 \mathrm{~L}$. For a woman in pregnancy and lactation period, the daily water intake should be $4.8 \mathrm{~L}$ and $3.3 \mathrm{~L}$ respectively (WHO, 2005). Besides body hydration, mineral water consumption supports essential macro-nutrients $\left(\mathrm{Ca}^{2+}, \mathrm{Cl}^{-}, \mathrm{PO}_{4}^{3-}, \mathrm{Mg}^{2+}, \mathrm{K}^{+}, \mathrm{Na}^{+}, \mathrm{SO}_{4}^{2-}\right)$ and micro-nutrients at trace levels $\left(\mathrm{Co}^{2+}, \mathrm{Co}^{3+}, \mathrm{Cr}^{3+}, \mathrm{Fe}^{2+}, \mathrm{Fe}^{3+}, F^{-}\right)$(Ingegerd, 2014; Quattrini et al., 2016; Whelton et al., 2007).

The mineral water bottling process consists of the following operation series: extraction of water from the well, drilling, water filtration, water treatment (iron and manganese removal), carbon dioxide enrichment, and, finally, bottling (Galanakis, 2020). The total soluble mineral content of the mineral waters is strongly dependent on $\mathrm{CO}_{2}$ concentration because the acidulated water dissolves more components from the rocks (Misund et al., 1999). The chemical composition and the mineral variety of water are strongly dependent on the original geological state, the rock types, and some other parameters: 
temperature, $\mathrm{CO}_{2}$ concentration, redox conditions, and adsorption complex type (Kis \& Baciu, 2014; van der Aa, 2003).

The consumption of mineral water types is recommended to different types of meat; therefore, the consumption of $\mathrm{CO}_{2}$-saturated mineral water is recommended with fatty foods, and the consumption of still mineral water is suitable for fish (Feru, 2012). Based on the dissolved mineral content, mineral water with low mineral content is more proper for newborns, and rich mineral water is suitable for sportsmen to compensate the minerals lost in transpiration (Feru, 2012).

The chemical composition of natural mineral waters in Romania collected from the original springs was analysed by many researchers (Kis et al., 2013; Papp \& Niţoi, 2006; Szakács \& Krézsek, 2006); however, bottled mineral waters were analysed by only a few (Levei et al., 2016).

The main objective of the present research is to investigate the fixed residue, $\mathrm{pH}$, and electrical conductivity of some commercially available bottled mineral waters from the Romanian market and to group them according to the abovementioned properties in order to provide supplementary information for the customers.

\section{Materials and methods}

In order to determine the $\mathrm{pH}$ and the conductivity of the mineral waters, a portable laboratory equipment was used (HI 9828 multimeter, Hanna Instruments). The measurements were carried out at room temperature $\left(20^{\circ} \mathrm{C}\right)$.

For the determination of the fixed residue, the water was evaporated entirely at $180^{\circ} \mathrm{C}$, and the fixed residue was measured using an analytical balance with four decimal precision. For the calculated fixed residue, the following equation was used:

$$
\operatorname{Rez}_{f i x}=\left[\left(m_{s p-d r y}-m_{w a-e m}\right) /\left(m_{s p-w e e t}-m_{w a-e m}\right)\right] \cdot \mathrm{CF},
$$

where: $\operatorname{Rez}_{f i x}$ - fixed residue at $180^{\circ} \mathrm{C}(\mathrm{mg} / \mathrm{L}) ; m_{s p-d r y}$ - the weight of the ampoule with samples (solid) after the evaporation $(\mathrm{g}) ; m_{w a-e m}-$ the weight of the empty ampoule $(\mathrm{g}) ; m_{s p-w e e t}$ - the weight of the ampoule with the sample (liquid) (g); CF - conversion factor $\left(10^{6}\right)$.

In order to add the confidence interval to the results, all samples were measured in triplicate. After the determination of the fixed residues, the mineral water brands were categorized into four groups, based on the European legislation: 1 - very low mineral content $(<50 \mathrm{mg} / \mathrm{L}), 2$ - low mineral content 
(50-500 mg/L), 3 - medium mineral content (500-1500 mg/L), and 4 - rich mineral content $(>1500 \mathrm{mg} / \mathrm{L})$ waters (EU Commission Directive, 2003). According to the $\mathrm{CO}_{2}$ content indicated on the label of the bottles, the waters were marked with st - still, spp - partially sparkling, and sp - sparkling.

In the local market (Miercurea Ciuc), the following 26 brands were available: Apa Craiului sp, AQUA Carpatica Forte sp, AQUA Carpatica st, Aquatique st, Artesia st, Azuga sp, Azuga st, Borsec sp, Bucovina st, Cezara light spp, Dorna st, Harghita Tiva sp, Izvorul Zăganului sp, K-classic sp, K-classic spp, Perla Harghitei sp, Perla Harghitei spp, Poiana Negri cump. sp, Siculaqua sp, Spring Harghita sp, Stânceni sp, Tuşnad sp, Tuşnad spp, Vâlcele sp, Wonder Spring st, and Zizin st.

Using the IBM SPSS Statistics 22 version, the hierarchical cluster analysis was used to classify the mineral water brands based on their similarities (centroid clustering method and Euclidean distance), and the results were presented in a dendrogram.

\section{Results and discussion}

The statistical description of mineral water characteristics based on $\mathrm{CO}_{2}$ content

The main characteristics of all studied brands are presented in Table 1. According to the $\mathrm{CO}_{2}$ content, the mineral waters were classified into three categories: still mineral waters, partially sparkling mineral waters, and sparkling mineral waters. Still mineral waters had higher $\mathrm{pH}$ values, ranging between 6.86 and 7.91. It is well-known that there is a strong correlation between electrical conductivity and mineral concentration - namely, high conductivity indicates a high ion and mineral concentration. The highest fixed residue was measured in the case of highly carbonated mineral water brands (Vâlcele sp - $2604 \mathrm{mg} / \mathrm{L}$, K-classic sp - $2384 \mathrm{mg} / \mathrm{L}$, Borsec sp - $1553 \mathrm{mg} / \mathrm{L}$ ). Based on the $\mathrm{pH}$ value, the partially sparkling mineral waters were situated between the still and sparkling mineral waters, with values between 5.72 and 6.19 , while the lowest $\mathrm{pH}$ value (Azuga sp - 4.7) was detected in the case of the sparkling mineral water brands. On average, the mineral content of the sparkling and partially sparkling mineral waters was quite similar, exhibiting $1008 \mathrm{mg} / \mathrm{L}$ and $987 \mathrm{mg} / \mathrm{L}$ respectively. 
Table 1. Statistical description of the studied mineral waters

\begin{tabular}{|c|c|c|c|c|c|c|c|c|}
\hline & & $\mathbf{N}$ & Min. & $\mathrm{P}(25)$ & Mean & Med. & $P(75)$ & Max. \\
\hline \multirow{3}{*}{$\begin{array}{l}\text { Still mineral } \\
\text { water }\end{array}$} & $\mathrm{pH}$ & & 6.86 & 7.49 & 7.59 & 7.73 & 7.83 & 7.91 \\
\hline & $\begin{array}{l}\text { Cond. } \\
\mu \mathrm{S} / \mathrm{cm}\end{array}$ & 8 & 93 & 182 & 298 & 296 & 365 & 573 \\
\hline & $\begin{array}{c}\text { Fix res. } \\
\text { mg/L }\end{array}$ & & 40 & 68 & 148 & 137 & 179 & 345 \\
\hline \multirow{3}{*}{$\begin{array}{l}\text { Partially } \\
\text { sparkling }\end{array}$} & $\mathrm{pH}$ & & 5.72 & 5.74 & 5.91 & 5.88 & 6.06 & 6.19 \\
\hline & $\begin{array}{l}\text { Cond. } \\
\mu \mathrm{S} / \mathrm{cm}\end{array}$ & 4 & 1003 & 1148 & 1507 & 1447 & 1807 & 2133 \\
\hline & $\begin{array}{c}\text { Fix res. } \\
\mathrm{mg} / \mathrm{L}\end{array}$ & & 756 & 788 & 1008 & 939 & 1160 & 1402 \\
\hline \multirow{3}{*}{ Sparkling } & $\mathrm{ph}$ & & 4.7 & 5.27 & 5.45 & 5.39 & 5.88 & 6.33 \\
\hline & $\begin{array}{l}\text { Cond. } \\
\mu \mathrm{S} / \mathrm{cm}\end{array}$ & 14 & 254 & 421 & 1216 & 1024 & 1813 & 3079 \\
\hline & $\begin{array}{c}\text { Fix res. } \\
\mathrm{mg} / \mathrm{L}\end{array}$ & & 104 & 480 & 987 & 711 & 1360 & 2604 \\
\hline
\end{tabular}

Abbreviations: $\mathbf{N}$ - number of samples; Min. - minimum; $\mathbf{P}(\mathbf{2 5})-25^{\text {th }}$ percentile; Mean - average; Med. - median; P(75) $-75^{\text {th }}$ percentile; Max. - maximum; Cond. - conductivity; Fix res. fixed residue.

Characterization of mineral waters based on the $p H$ value

As it can be observed in Figure 1, the dissolved $\mathrm{CO}_{2}$ content highly influences mineral waters' pH. Three sparkling mineral waters, Azuga, Izvorul Zăganului, and Apa Craiului, had pH values lower than 5. For 12 types of mineral waters (46.15\%), pH values varied between 5 and 6 , while 4 and 7 types of mineral waters exhibited $\mathrm{pH}$ values in the range of 6-7 and 7-8 respectively.

\section{Characterization of mineral waters based on electrical conductivity}

The relationship between the fixed residue and the conductivity of the mineral waters was strong (Pearson correlation: $\mathrm{r}=0.96$ ). The conductivity varied between 92 and $3078 \mu \mathrm{S} / \mathrm{cm}$ (Figure 2).

For 14 mineral water brands, conductivity was lower than $600 \mu \mathrm{S} / \mathrm{cm}$; from these brands, 8 were still mineral waters and 6 were sparkling. The conductivity of the other 12 mineral waters was higher than $1000 \mu \mathrm{S} / \mathrm{cm}$, including eight sparkling and four partially sparkling mineral waters. 


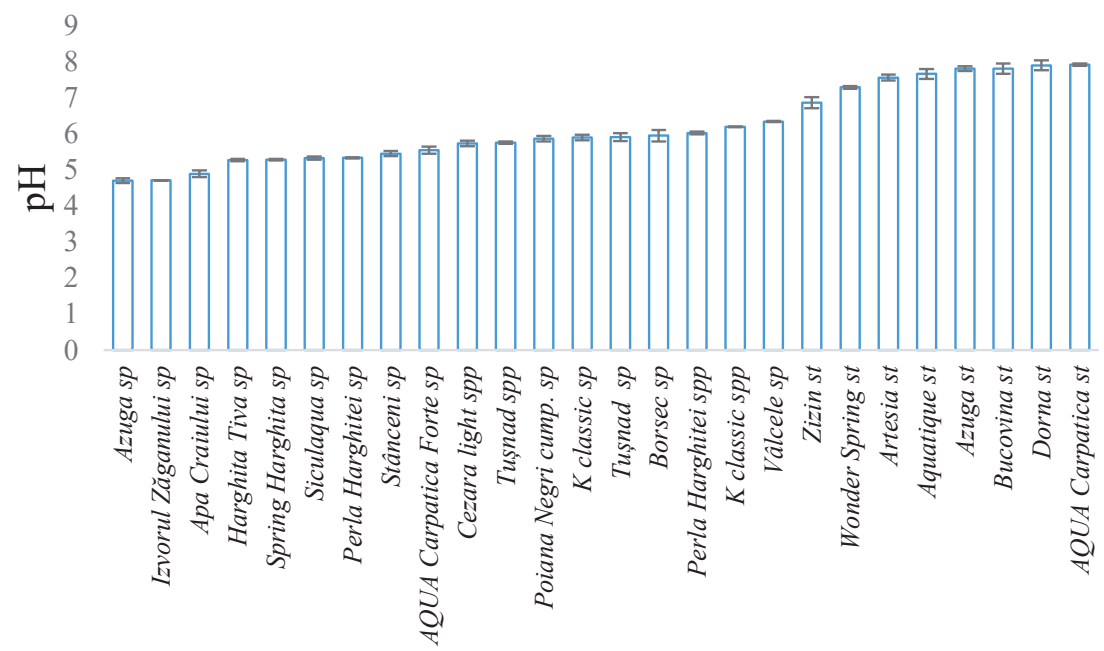

Figure 1. The $\mathrm{pH}$ values of the studied mineral waters

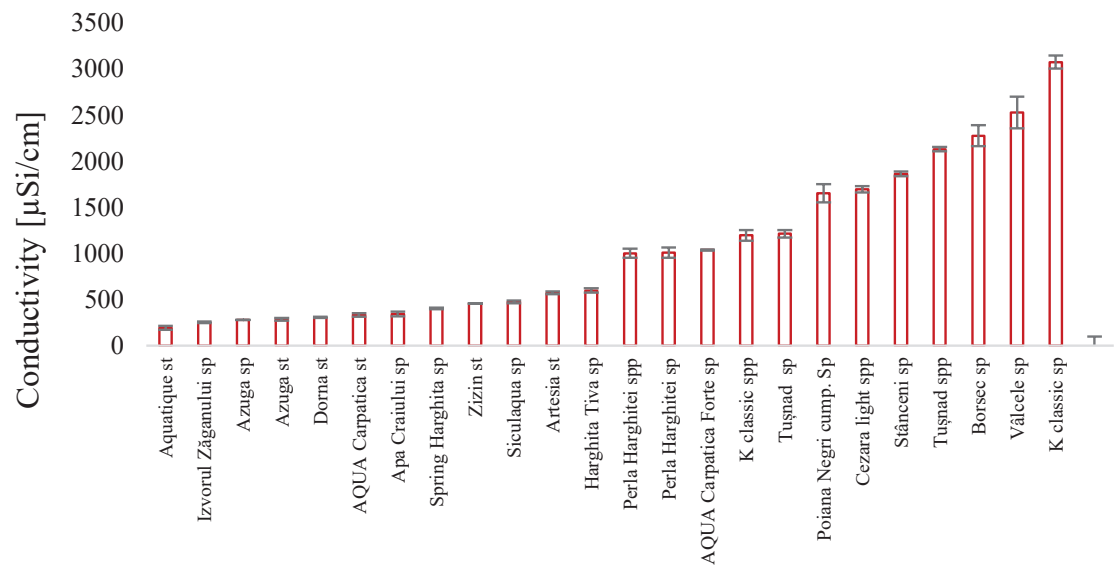

Figure 2. Electrical conductivity of the mineral waters

Classification of mineral waters based on the fixed residue

According to the results obtained for the 26 studied brands for the fixed residue, we can emphasize that in the case of 12 brands $(46.2 \%)$ the fixed residue was between 50 and $500 \mathrm{mg} / \mathrm{L}$, which corresponds to a low mineral 
content, followed by 10 brands (38.5\%) with medium mineral content. However, one brand was detected as having a very low mineral content, while brands with rich mineral content represented $11.5 \%$ of the samples, namely Borsec sp, K-classic sp, and Vâlcele sp (Table 2).

Table 2. Mineral water classification based on the fixed residue

\begin{tabular}{|c|c|c|c|}
\hline Fix res. at $180{ }^{\circ} \mathrm{C}$ & No. & $\%$ & Brand description \\
\hline $\begin{array}{c}\text { Very low } \\
(<50 \mathrm{mg} / \mathrm{L})\end{array}$ & 1 & 3.85 & Wonder Spring st \\
\hline $\begin{array}{c}\text { Low } \\
(50-500 \mathrm{mg} / \mathrm{L})\end{array}$ & 12 & 46.2 & $\begin{array}{l}\text { Bucovina st, Aquatique st, Azuga sp, } \\
\text { Dorna st, Izvorul Zăganului sp, Azuga st, } \\
\text { AQUA Carpatica st, Apa Craiului sp, } \\
\text { Zizin st, Artesia st, Siculaqua sp, } \\
\text { Spring Harghita sp }\end{array}$ \\
\hline $\begin{array}{c}\text { Medium } \\
(500-1500 \mathrm{mg} / \mathrm{L})\end{array}$ & 10 & 38.5 & $\begin{array}{l}\text { Harghita Tiva sp, Perla Harghitei sp, } \\
\text { AQUA Carpatica Forte sp, Perla Harghitei spp, } \\
\text { K-classic spp, Cezara light spp, } \\
\text { Poiana Negri cump. sp, Stânceni sp, } \\
\text { Tuşnad spp, Tuşnad sp }\end{array}$ \\
\hline $\begin{array}{c}\text { Rich } \\
(>1500 \mathrm{mg} / \mathrm{L})\end{array}$ & 3 & 11.5 & Borsec sp, K-classic sp, Vâlcele sp \\
\hline
\end{tabular}

Two categories were identified based on the fixed residue values as follows: very low and low (Figure 3) and medium and rich mineral content (Figure 4). The lowest fixed residue was detected in the case of Wonder Spring and the highest in Vâlcele mineral waters.

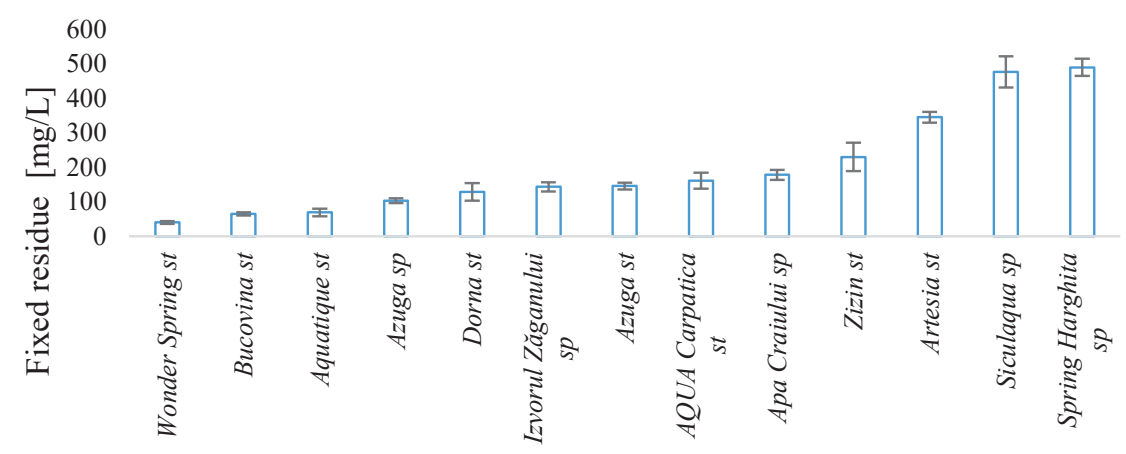

Figure 3. Very low and low fixed residue mineral water brands 


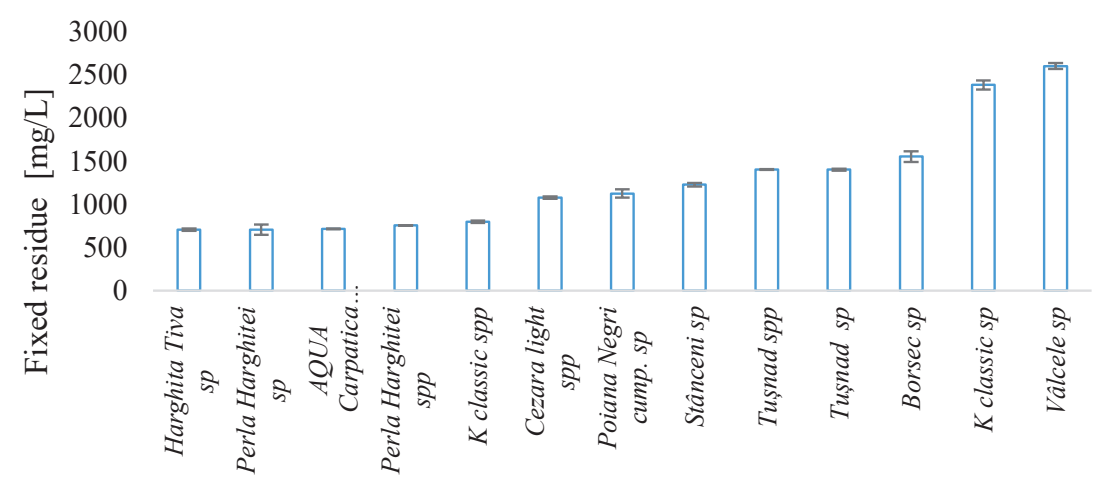

Figure 4. Medium and rich fixed residue mineral water brands

Comparison of the studied waters with some European waters

The measured parameters were compared to other European mineral waters (Table 3). The lowest and highest $\mathrm{pH}$ values were registered in Italy $(4.1,8.8)$, while the measured conductivity varied on a large scale from 18 to $26000 \mu \mathrm{S} / \mathrm{cm}$. Based on $\mathrm{pH}$ values, the Romanian mineral waters' variability (4.7-7.91) was similar to that of Estonian mineral waters (4.7-7.76). The maximum value of measured electrical conductivity in Romanian waters (3079 $\mu \mathrm{S} / \mathrm{cm})$ was almost identical to the one measured in Italian mineral waters $(3020 \mu \mathrm{S} / \mathrm{cm})$.

Table 3 . The $\mathrm{pH}$ and the electrical conductivity of mineral waters from Europe

\begin{tabular}{lccc}
\hline & $\mathbf{p H}$ & Cond,$\mu \mathbf{S} / \mathbf{c m}$ & Reference \\
\hline Romania & $4.7-7.91$ & $92-3079$ & \\
Serbia & $5.6-7.5$ & $340-4560$ & (Petrović et al., 2010) \\
Italy & $4.1-8.8$ & $18-3020$ & (Dinelli et al., 2010) \\
Estonia & $4.7-7.76$ & $175-4370$ & (Bityukova \& Petersell, 2010) \\
Poland & $4.7-8.3$ & $188-6510$ & (Astel et al., 2014) \\
Hungary & $5.3-8.3$ & $250-26000$ & (Fugedi et al., 2010) \\
Spain & $6-8.1$ & $30-1257$ & (Devesa et al., 2012) \\
Slovakia & $6-6.75$ & & (Dušan et al., 2010) \\
Croatia & $6-7.9$ & $340-3680$ & (Peh et al., 2010) \\
Germany & $3.8-8.10$ & $38.1-6340$ & (Birke et al., 2010) \\
\hline
\end{tabular}


Comparison of the studied parameters with the reported ones on the labels

The comparative analysis between the determined and the reported values on the labels is presented in Table 4. We would like to mention that not all studied brands displayed the $\mathrm{pH}$ values and fixed residues on the labels.

Table 4. The comparison of the measured ${ }^{\mathrm{m}}$ and the reported ${ }^{\mathrm{r}}$ values

\begin{tabular}{lcccc}
\hline & $\mathbf{p H}^{\mathbf{m}}$ & $\mathbf{p H}^{\mathbf{r}}$ & Fix res $^{\mathbf{m}}$ & Fix res $^{\mathbf{r}}$ \\
\hline Apa Craiului sp & 4.89 & 5.00 & 178 & 194 \\
Aquatique st & 7.66 & 7.8 & 70 & 90 \\
Artesia st & 7.55 & & 345 & 465.5 \\
Azuga sp & 4.70 & & 104 & 191 \\
Azuga st & 7.80 & & 146 & 191 \\
Borsec sp & 5.94 & 5.64 & 1554 & 1655 \\
Bucovina st & 7.80 & 7.27 & 65 & 78 \\
Cezara light spp & 5.72 & 6.11 & 1079 & \\
Dorna st & 7.89 & 7.71 & 129 & 192 \\
Izvorul Zăganului sp & 4.70 & & 144 & 147 \\
K-classic sp & 5.89 & & 2384 & 2453 \\
K-classic spp & 6.19 & & 798 & 920 \\
Poiana Negri cump. Sp & 5.86 & 5.65 & 1125 & 1173 \\
Spring Harghita sp & 5.28 & 5.3 & 490 & 510 \\
Stânceni sp & 5.45 & 5.37 & 1229 & 1375 \\
Tuşnad sp & 5.90 & & 1403 & 1674 \\
Tuşnad spp & 5.75 & & 1402 & 1674 \\
Vâlcele sp & 6.33 & 6.55 & 2604 & 2440 \\
Wonder Spring st & 7.28 & & 40 & 81.4 \\
Zizin st & 6.86 & & 230 & 202 \\
\hline
\end{tabular}

Hierarchical Cluster Analysis

In order to find similarities and differences among the studied samples, the hierarchical cluster analysis was carried out, taking into consideration the $\mathrm{pH}$, the electrical conductivity, and the fixed residue. The results showed two main clusters with sub-clusters (Figure 5). Cluster 1 contained two sub-clusters. The sub-cluster 1.1 contained 8 still mineral waters, characterized by average high $\mathrm{pH}(7.59)$ and low electrical conductivity $(298 \mu \mathrm{S} / \mathrm{cm})$ and fixed residue (148 mg/L). The 1.2 sub-cluster covers the majority of the studied brands (16), represented by partially sparkling and sparkling mineral waters. In comparison with cluster 1.1, lower $\mathrm{pH}(5.49)$, higher electrical conductivity $(1090 \mu \mathrm{S} / \mathrm{cm})$ and fixed residue $(804 \mathrm{mg} / \mathrm{L})$ were observed. Two brands, K-classic st and 
Vâlcele sp, appeared in cluster 2, which formed a group of waters with very high fixed residue and electrical conductivity $(2494 \mathrm{mg} / \mathrm{L}, 2805 \mu \mathrm{S} / \mathrm{cm})$.

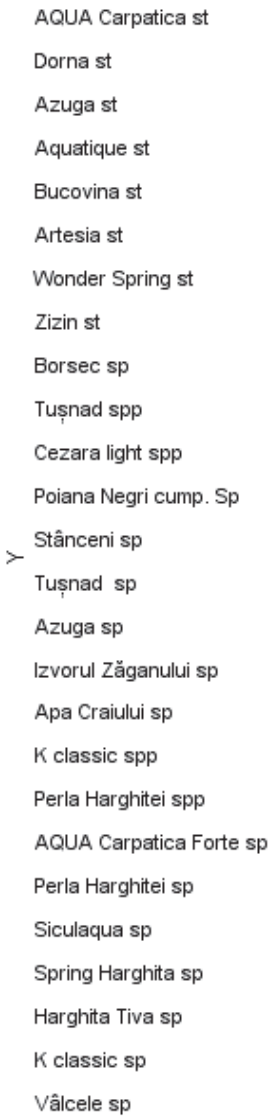

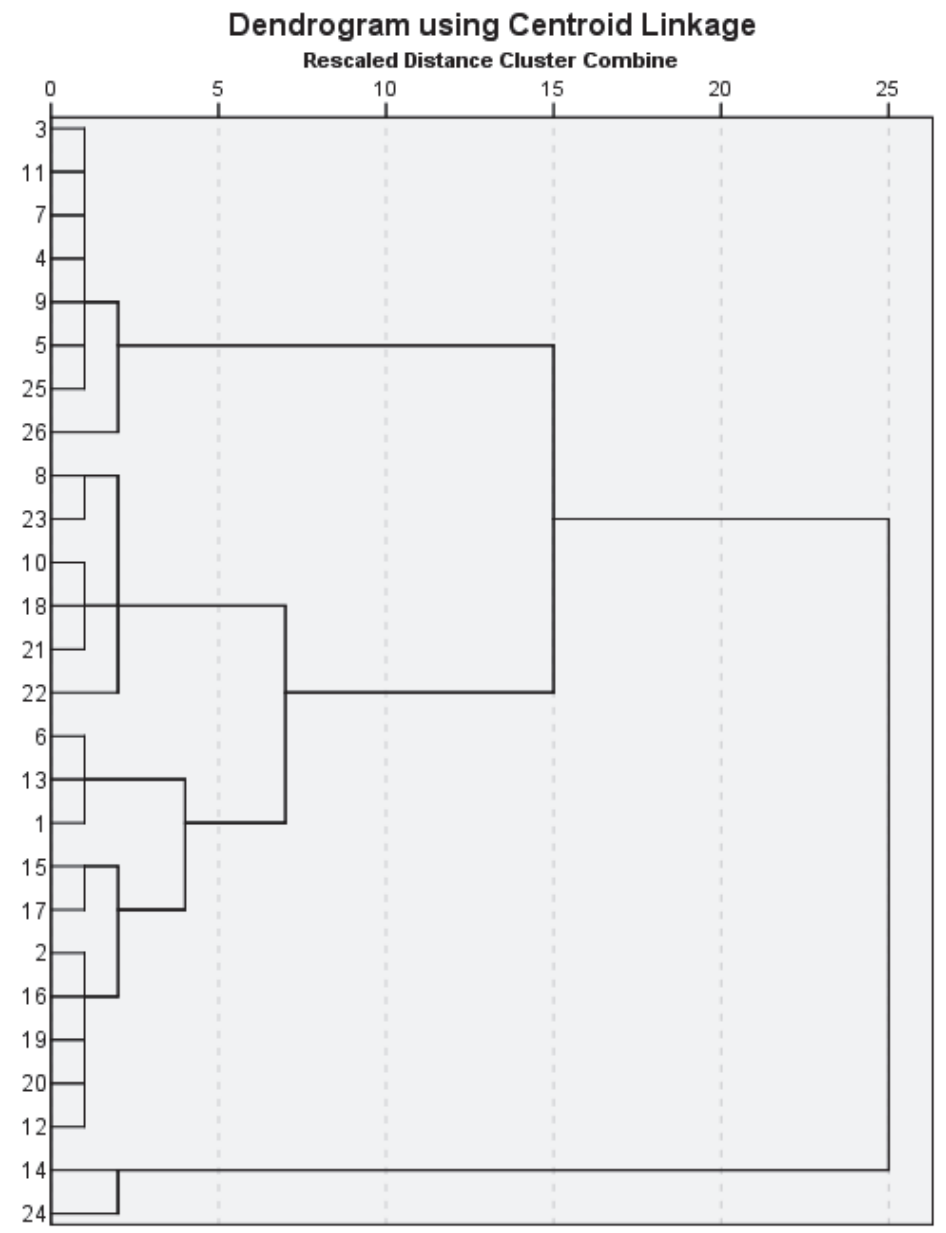

Figure 5. Classification of the mineral waters by hierarchical cluster analysis

\section{Conclusions}

In this study, three parameters ( $\mathrm{pH}$, electrical conductivity, and fixed residue) were determined for selected commercialized mineral waters and analysed in more detail using descriptive statistics. The results revealed that the mineral 
content was very low for $3.84 \%$, low for $46.2 \%$, medium for $38.5 \%$, and rich for $11.5 \%$ of the selected waters. The total mineral content of sparkling and partially sparkling mineral waters was remarkably close, as we found close values for the electrical conductivity. According to the hierarchical cluster analysis, cluster 1.1 covers the still mineral waters with high $\mathrm{pH}$ and low fixed residue. Cluster 1.2 was represented by the medium mineral content, and in cluster 2 two brands were observed with very high fixed residue. There were no considerable differences between the reported values on the labels of the bottles and the values determined by our team.

\section{Acknowledgements}

The authors are thankful for the financial support provided by the University of Pécs, the Doctoral School of Chemistry Scholarship, and Sapientia Hungarian University of Transylvania, where the laboratory experiments were carried out.

\section{References}

[1] Astel, A., Michalski, R., Łyko, A., Jabłońska-Czapla, M., Bigus, K., Szopa, S., Kwiecińska, A., Characterization of bottled mineral waters marketed in Poland using hierarchical cluster analysis. Journal of Geochemical Exploration, 143. (2014) 136-145.

[2] Birke, M., Rauch, U., Harazim, B., Lorenz, H., Glatte, W., Major and trace elements in German bottled water, their regional distribution, and accordance with national and international standards. Journal of Geochemical Exploration, 107. (2010) 245-271.

[3] Bityukova, L., Petersell, V., Chemical composition of bottled mineral waters in Estonia. Journal of Geochemical Exploration, 107. (2010) 238244.

[4] Devesa, R., Platikanov, S., Garcia, V., Fonseca, I., Rulla, E., Tauler, R., Influence of minerals on the taste of bottled and tap water: A chemometric approach. Water Research, 47. (2012) 693-704.

[5] Dinelli, E., Lima, A., De Vivo, B., Albanese, S., Cicchella, D., Valera, P., Hydrogeochemical analysis on Italian bottled mineral waters: Ef- 
fects of geology. Journal of Geochemical Exploration, 107. (2010) 317335 .

[6] Dušan, B., Jozef, K., Igor, S., Peter, M., Pavel, L., Daniel, P., Jarmila, B., Daniel, M., Mineral waters in Slovakia - Evaluation of chemical composition stability using both historical records and the most recent data. Journal of Geochemical Exploration, 107. (2010) 382-390.

[7] EU Commission Directive. Commission Directive 2003/40/EC. Official Journal of the European Union. (2003) 34-39.

[8] Feru, A., Ghidul Apelor Minerale Naturale. NOVIS. (2012) 1-57.

[9] FRD Center Market. The mineral bottled water sector in Romania 2016. FRD Center Market Entry Services Publication. (2016) 1-16.

[10] Fugedi, U., Kuti, L., Jordan, G., Kerek, B., Investigation of the hydrogeochemistry of some bottled mineral waters in Hungary. Journal of Geochemical Exploration, 107. (2010) 305-316.

[11] Galanakis, C. M., Trends in non-alcoholic beverages. Academic Press. (2020).

[12] Ingegerd, R., Drinking water minerals and mineral balance. Environmental Science and Technology. (2014) 1-137.

[13] Ionete, R. E., Popescu, R., Costinel, D., An isotopic survey of some mineral water resources in the Carpathian chain (Romania). Environmental Engineering and Management Journal, 14. (2015) 2445-2456.

[14] Kis, B.-M., Baciu, C., The mineral waters from the Eastern Carpathians: A chemical review. Studia Universitatis Babeş-Bolyai - Ambientum, 59. (2014) 71-80.

[15] Kis, B.-M., Baciu, C., Kékedy-Nagy, L., A statistical approach to the mineral waters of Transylvanian Basin-Eastern Carpathians boundary. Studia Universitatis Babeş-Bolyai - Ambientum, 58. (2013) 55-63.

[16] Levei, E. A., Hoaghia, M.-A., Senila, M., Miclean, M., Tanaselia, C., Carstea, E. M., Chemical composition of some Romanian bottled natural mineral waters. Studia Universitatis Babeş-Bolyai - Chemia, 61. (2016) 391-400. 
[17] Misund, A., Frengstad, B., Sewersd, U., Reimanna, C., Variation of 66 elements in European bottled mineral waters. Science of the Total Environment, 7. (1999) 21-41.

[18] Papp, D. C., Niţoi, E., Isotopic composition and origin of mineral and geothermal waters from Tuşnad Băi Spa, Harghita Mountains, Romania. Journal of Geochemical Exploration, 89. (2006) 314-317.

[19] Peh, Z., Šorša, A., Halamić, J., Composition and variation of major and trace elements in Croatian bottled waters. Journal of Geochemical Exploration, 107. (2010) 227-237.

[20] Petrović, T., Zlokolica-Mandić, M., Veljković, N., Vidojević, D., Hydrogeological conditions for the forming and quality of mineral waters in Serbia. Journal of Geochemical Exploration, 107. (2010) 373-381.

[21] Quattrini, S., Pampaloni, B., Brandi, M. L., Natural mineral waters: Chemical characteristics. Clinical Cases in Mineral and Bone Metabolism, 13. (2016) 173-180.

[22] Sharma, R. K., Suggestion for establishment of minimum limits for constituent minerals in drinking water. Journal of Fertilizers and Pesticides, 8. (2017) 8-10.

[23] Szakács, A., Krézsek, C., Volcano-basement interaction in the Eastern Carpathians: Explaining unusual tectonic features in the Eastern Transylvanian Basin, Romania. Journal of Volcanology and Geothermal Research, 158. (2006) 6-20.

[24] The Council of the European Communities. On the approximation of the laws of the Member States relating to the exploitation and marketing of natural mineral waters (80/777/EEC). Official Journal of European Communities, 10. (1980).

[25] van der Aa, N. G. F. M., Classification of mineral water types and comparison with drinking water standards. Environmental Geology, 44. (2003) 554-563.

[26] Vaselli, O., Minissale, A., Tassi, F., Magro, G., Seghedi, I., Ioane, D., Szakacs, A., A geochemical traverse across the Eastern Carpathians (Romania): Constraints on the origin and evolution of the mineral water and gas discharges. Chemical Geology, 182. (2002) 637-654. 
[27] Whelton, A., Dietrich, A. M., Burlingame, G. A., Duncan, S. E., Minerals in drinking water: Impacts on taste and importance to consumer health. Water Science and Technology. (2007) 1-215.

[28] WHO. Nutrients in drinking water. Protection of the Human Environment Water, Sanitation and Health, Geneva. (2005). 